\title{
Remarks on the Iconographic Motif of the Birdman in Mesopotamian Glyptic Art of the Third Millennium BC
}

\author{
DOMINIKA MAJCHRZAK
}

\begin{abstract}
The iconographic motif of the birdman emerged in Mesopotamian glyptic art in the Early Dynastic period and disappeared at the end of the Akkadian period. Its meaning remains ambiguous, particularly due to the fact that the figure is represented in scenes of varying character and it cannot be identified with any character known from myths. Sometimes, the creature may be recognised as a deity based on a horned crown, yet this is not always the case. Among the deities attested in the scenes with birdman, one can easily identify Shamash and Enki. The examined material contains 62 published seals or seal impressions with the birdman motif, both from the Early Dynastic and the Akkadian period. The latest monographic studies of this subject were published in the 1950s. Interpretations presented by the authors of said works, though often quoted in the research on the motif, seem to lack proper argumentation and, to an large extent, are outdated due to a considerable progress of the research on Sumero-Akkadian iconography and an increase, although modest, in study material, among other things. In light of the above, it is worth analysing this motif one more time.
\end{abstract}

Keywords: birdman, glyptic, seal, seal impression, Akkadian period, Early Dynastic period, Enki, Shamash

Dominika Majchrzak, Institute of Mediterranean and Oriental Cultures, Polish Academy of Science, Warszawa; dmnkmajchrzak@gmail.com

Mesopotamian seals and impressions dated to the Early Dynastic (ED) period featured an iconographic motif of a birdman - a half-human and half-bird creature. This motif continued in glyptics until the Akkadian period, after which it disappeared. The author analyses 62 published seals or seals impressions with the birdman motif. ${ }^{1}$ In the canonical

\footnotetext{
${ }^{1}$ Amiet 1952: Figs 4, 13-14; 1980: Pls 97/1268, 106/1396-1402, 108/1439-1440, 1442, 113/1503-1504, 132/1783-1784; Buren 1933: Pls IV/16, V/18; 1953: Fig. 1; Boehmer 1965: Pls XXIV/276, XXXIII/391, XLII/496-497, XLIII/503, 509, 511-513, XLIV/515-516, 519, 521; Collon 1982: P1. XXIX/200-206; Buchanan 1966: no. 802; Frankfort 1955: Pls 55/580, 59/619, 62/655, 65/694; Matthews 1997: Pls XII/92, XVIII/187, 193, XXIX/365-367; Matthews, Matthews, McDonald 1994: Fig. 13/9; Moortgat 1988: Pl. 30/223-224, 226; Ravn 1960: no. 22; Rova 2012: Fig. 5/68; Speiser 1935: P1. LX/62; Ward 1910: Figs. 293-294, 298, 300b.
} 


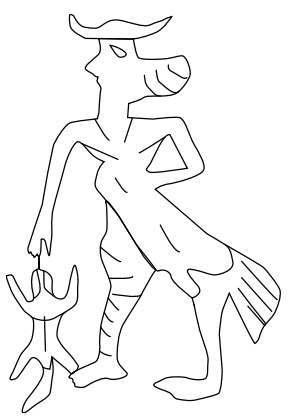

1. Canonical image of the birdman, detail from the Akkadian period seal; not to scale (Drawing: D. Majchrzak; based on: Ward 1910: Fig. 300b).

form the discussed hybrid was represented as a bearded man from the waist up and as a bird from the waist down, with a feathered tail, bird feet and commonly claws (Fig. 1). Sometimes, a beak or wings were added but, in the present author's opinion, these elements might have served the purpose of filling the free space of the design, as suggested by the composition of these representations. ${ }^{2}$ Common attributes of this hybrid figure included a pole and a stylised plant, either branch or cereal ears. ${ }^{3}$ Other less frequently attested attributes were a spear or a sceptre. ${ }^{4}$ On one seal, the hybrid was shown with a lizard in its hand. ${ }^{5}$ In some rare instances, the birdman was depicted wearing a horned crown, ${ }^{6}$ which may indicate its divine status.

The figure of the birdman in glyptics has been discussed in only a few studies ${ }^{7}$ and the present paper constitutes another attempt at analysing this motif. It is particularly interesting because of the multiple roles attributed to the hybrid. Its representations have been found in various types of scenes, its reception remains ambiguous, and its role is not easy to interpret due to the fact that no analogous figure has been identified in Sumero-Akkadian mythology. There is no certainty whether the birdman always symbolised the same character, or whether it represent various mythological figures depending on the type of representation.

The analysed material featuring the birdman motif comprised 20 artefacts from the Early Dynastic period and 42 from the Akkadian period from southern and northern Mesopotamia. Only about $43 \%$ of all the examples are of known provenience $(80 \%$ of Early Dynastic period examples and $26 \%$ of those from the Akkadian period) while the remaining ones were obtained in the antiquarian market. ${ }^{8}$ It is also difficult to determine

2 The beak is attested on $5 \%$ and the wings on $14 \%$ of examples.

$331 \%$ of the examined material.

$46 \%$ of the examined material.

5 Ward 1910: 106, Fig. 300b.

${ }^{6}$ Collon 1982: 76, Pl. XXI/145; Ward 1910: 106, Fig. 300b; Ravn 1960: 28-30, no. 22; Amiet 1952: 158, Fig. 14.

7 The most important ones are Amiet 1952 and Buren 1953.

${ }^{8}$ Among Early Dynastic seals or seal impressions with the birdman motif, seven were found in Tell Brak, two in Tell Fara, two in Kish, single pieces in Tell Asmar, Tell Beydar, Ur, Susa and one in northern Syria. Among Akkadian examples, two were found in Tell Brak, two in Ur, two in Tell Asmar, single pieces in Nippur, Tell Fara, Tello, Chagar Bazar and Tepe Gawra; for references see above, note 1. 
2. A seal from Tell Asmar, ED I(?) period; dimensions: 3.5 x c. $2.1 \mathrm{~cm}$; not to scale (Drawing: D. Majchrzak; based on: Frankfort 1955: Pl. 44/471).

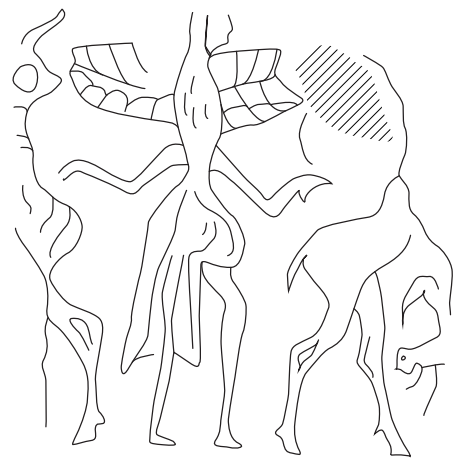

whether this motif first appeared in north or south Mesopotamia. As there are only 16 Early Dynastic finds of known origin, this group is too small to allow to draw final conclusions about this matter. Nonetheless, there are certain indications that the motif did not originate in southern Mesopotamia. This is suggested, among others, by the chronological attestation of the birdman motif, which, despite its apparent popularity in the Akkadian period, disappeared completely towards the end of the third millennium BC. ${ }^{9}$ A similar phenomenon can be observed in relation to other motifs, alongside which representations of the hybrid sometimes appeared, ${ }^{10}$ for instance, 'building of a ziggurat' scene or processions of the boat-god. ${ }^{11}$ The current state of research suggests that the 'building of a ziggurat' and processions of the boat-god themes originate in north Babylonia, as they were mostly attested in this area and seem to be atypical for the Sumerian glyptic art. ${ }^{12}$ In the present author's opinion the birdman motif may belong to this group.

\section{EARLY DYNASTIC PERIOD}

The earliest known representation of the birdman was found on a seal from Tell Asmar (Fig. 2), ${ }^{13}$ but the figure is depicted in a clearly non-canonical manner. It seems that the engraver was only attempting to create a half-human, half-bird figure. The seal shows a man of severely distorted proportions standing sideways in a tucked up tunic, which may have been intended to imitate a bird's tail, and with spread wings attached at the shoulders. The hybrid is extending its arms towards hoofed animals flanking it on both sides, shown in an upright position. Similar depictions of the birdman are attested in several other early representations. ${ }^{14}$ Frequently, they seem to be an attempt to create such a composite form

\footnotetext{
9 Lawecka 2010: 173-199.

10 The 'building of a ziggurat' motif is attested alongside the birdman motif in at least two cases (Amiet 1980: Pls 108/1442, 132/1784), whereas the procession of the boat-god - on at least eight examples (Amiet 1952: Fig. 10; 1980: Pls 108/1440, 1442, 113/1503-1504, 132/1782-1784).

11 Non-Sumerian origin of these two motifs was already pointed out by Pierre Amiet (Amiet 1980: 182).

12 Lawecka 2009: 122-123.

13 Frankfort 1955: 28, Pl. 44/471; Ławecka 2010: 193-194.

14 Amiet 1952: 152-153, Figs 1, 3-4.
} 
that would best display the figure's features. In all these cases, the hybrid is flanked by animals standing upright. These artefacts were initially dated to the Early Dynastic II period, ${ }^{15}$ but in present author's opinion it seems more probable that they belonged to the terminal Early Dynastic I period. ${ }^{16}$ It is worth mentioning that the earliest dated examples show the birdman en face. On the later artefacts - dated from the Early Dynastic IIIA period to the end of the Akkadian period - the hybrid was depicted exclusively in profile.

At the beginning of the Early Dynastic III period, there emerged a canon of the birdman iconography - a canon that remained unchanged until the motif ceased to appear in the glyptic art of Mesopotamia. The creature's upper body is human, most likely male, often bearded, while its lower body is that of a bird (see Fig. 1) ${ }^{17}$ The birdman was represented in scenes with animals, sometimes accompanied by humans and various fantastic creatures, including other hybrids like the scorpionman or the bullman. Such a depiction is known, for instance, from a seal found at Tell Brak (Fig. 3a). ${ }^{18}$ In this particular representation, the birdman was given wings, though, as it was suggested above, such a treatment may be explained by a desire to cover all the space available on the seal. Two dots and a wavy line ${ }^{19}$ present on the same seal may be considered as the filling motifs. ${ }^{20}$ Plants shown next to the hybrid indicate its connection with the world of vegetation.

Pierre Amiet claimed that the birdman in the Early Dynastic period was always shown as a non-aggressive character, which could be contrasted with the representations of the creature in the Akkadian period. ${ }^{21}$ However, there are known Early Dynastic depictions of the birdman in the context of a battle or contest scene, which contradicts the hybrid's purely peaceful nature. One example of such a scene is presented in Fig. 3b. ${ }^{22}$ It shows the birdman in its canonical form holding a spear in one hand with which it strikes down a scorpionman lying below. The scene also features other animals and hybrids, and the whole design is complemented by a solar disc, the symbol of Shamash. According to the Epic of Gilgamesh, the scorpion-people were servants of Shamash, ${ }^{23}$ therefore this scene could be interpreted as a symbolic fight between the birdman and the sun-god. What is more, the hybrid seems to be victorious, triumphing over the fallen scorpionman.

Another thematic group of seals involving the birdman are processions of the boat-god. This motif appeared already prior to the Early Dynastic III period and continued throughout the Akkadian period. ${ }^{24}$ It is believed that such representations could symbolise

15 Lawecka 2010: 197.

${ }^{16}$ Currently, there is a tendency to no longer discern the Early Dynastic II sub-period. In the Early Dynastic IIIA period, the canon of the birdman was already clearly defined.

17 Hempelmann 2004: 40-44.

18 Matthews 1997: 244, P1. XVIII/195.

19 However, the wavy line may be a symbolic representation of a snake.

${ }^{20}$ Collon 1995b: 69-76.

21 Amiet 1952: 149-167.

22 Ławecka 2010: 193, Fig. 7-25:4.

23 Epic of Gilgamesh: 70 (the translation in question is a synthesis of the Babylonian, Sumerian and Akkadian versions of the myth); Green 1994: 242.

24 Ławecka 2009: 123. 


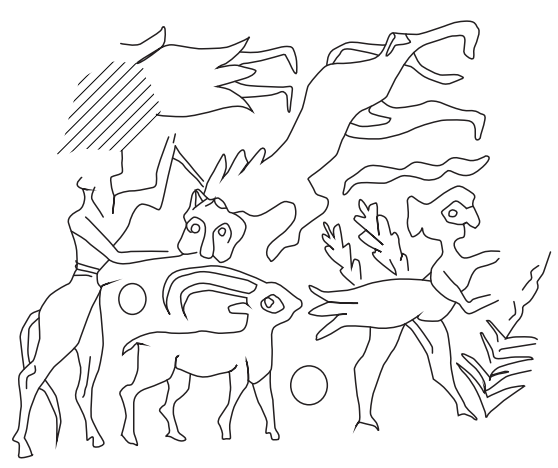

a

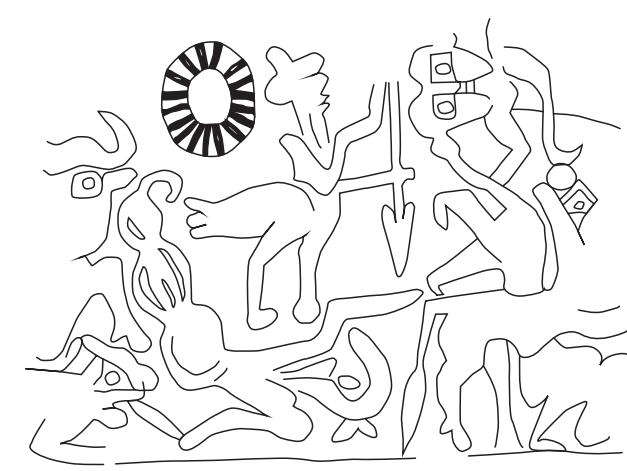

b

3a. A seal from Tell Brak, ED III period; dimensions: 2.3 x 2.75cm; b. a seal impression from Tell Brak, ED III period; $2.3 \mathrm{~cm}$ height; not to scale (Drawing: D. Majchrzak; based on: a. Matthews 1997: Pl. XVIII/195; b. Ławecka 2010: Fig. 7-25:4).

the sun's journey across the sky during the day and through the underworld during the night, or the mutual relationship of the sun and vegetation. ${ }^{25}$ Pierre Amiet and Elizabeth van Buren have suggested that the Early Dynastic image of the birdman is closely related with that of the boat-god, ${ }^{26}$ but in the analysed Early Dynastic material this deity was present only in about $30 \%$ of depictions. ${ }^{27}$ The motif of the boat-god procession was only one of several possible variants of portraying the birdman, and it certainly was not the predominant one.

One of the artefacts from this group (Fig. 4a) shows a scene divided into two registers. ${ }^{28}$ The lower one depicts yet another popular theme of this period, namely the so-called 'building of a ziggurat' scene. The upper register features the birdman portrayed in its canonical form with a wing added just above the tail. It is the only figure turned to the right, facing the boat-god, with one hand stretched in a greeting gesture towards the deity, and holding a stick in the other. A scorpion is placed between these two figures. The boat-god is holding an oar, and yet another deity is seated in the boat and is also rowing. Two cereal ears are also depicted on the boat. Next to the birdman, there are three symbols associated with the representation of boat-god processions: a quadruped, a plough, and a ceramic vessel.

Another noteworthy example of an Early Dynastic depiction of the discussed figure was also found at Tell Brak (Fig. 4b). ${ }^{29}$ It shows a hybrid - most probably a birdman ${ }^{30}$ - possibly restrained as in the Akkadian period (see below) with one arm upraised and

25 Buren 1953: 51.

26 Amiet 1952: 155; Buren 1953: 50.

27 See above, note 10 .

28 Lawecka 2010: 193, Fig. 7-23:1.

29 Matthews 1997: 230, Pl. XII/92.

${ }^{30}$ Donald Matthews does not identify the depicted figure as the birdman. However, the present author does believe that certain factors - namely the distinctive ending of the creature's body, the fact that the hybrid is being led, as well as the entire composition which is very typical for this kind of representation - make this identification both viable and plausible (see: Matthews 1997: 230). 


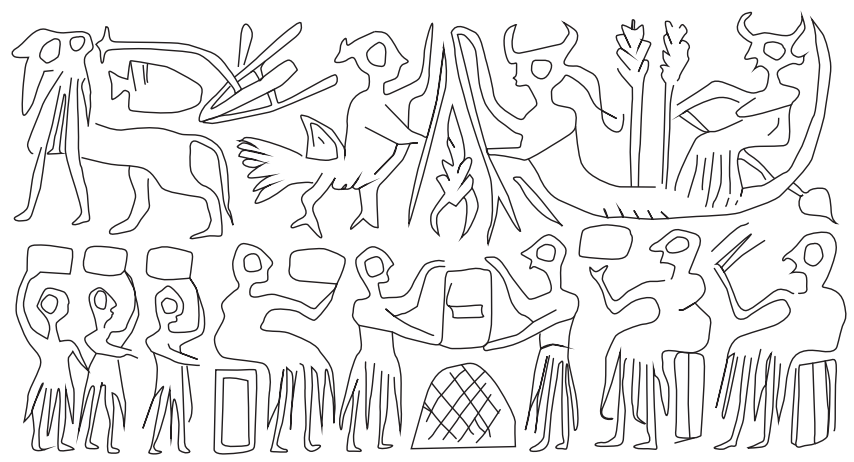

a

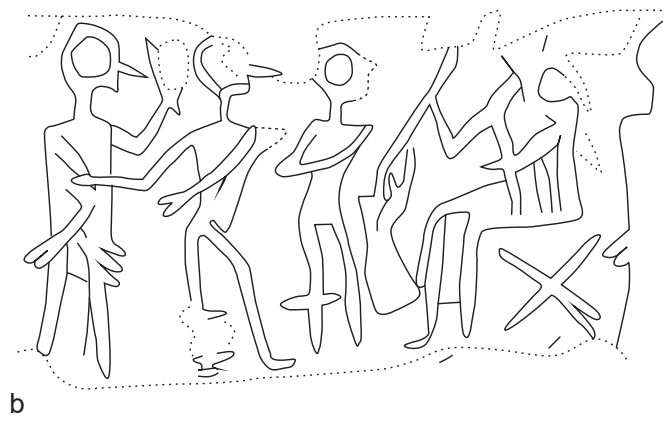

4a. A seal of an unknown provenance, ED III period; dimensions: 3.1 x 1.9cm; b. a seal impression from Tell Brak, ED III period; dimensions: 2 x 1.5cm; not to scale (Drawing: D. Majchrzak; based on: a. Ławecka 2010: Fig. 7-23:1; b. Matthews 1997: P1. XII/92).

holding a short stick; its other arm is being held by a figure standing in front of the creature, while a third figure is standing closer to the throne. All three are facing a deity sitting on the throne and drinking some kind of beverage through a long straw. ${ }^{31}$ The depiction is particularly interesting because all other examples of the scene of bringing the birdman before a deity are associated with the Akkadian period. ${ }^{32}$ This example, however, shows that the motif first emerged in the Early Dynastic period.

In summary, it is possible to distinguish several types of Early Dynastic scenes featuring the birdman. The first group consist of early, experimental depictions, in which the hybrid is shown en face with outstretched arms (and wings if they are added). It is usually accompanied by animals standing upright (such scenes are also known as 'contest scenes'). All the remaining thematic groups concern the canonical depiction of the birdman. The theme of contests with animals is continued and developed to include other hybrids as well. Such

\footnotetext{
${ }^{31}$ Its divine character may be inferred based on the difference in size between the depicted figures, as the enthroned one is much larger than the others.

${ }^{32}$ Amiet 1952: 156-157.
} 
scenes attest to the fact that in the Early Dynastic period, the birdman was not always a nonaggressive figure. Another set of depictions is composed of processions of the boat-god which include the hybrid. Sometimes these scenes are accompanied by other motifs like 'building of a ziggurat' or 'adoration of an altar'. On one Early Dynastic seal, the author has identified the scene of leading the hybrid before an enthroned deity, particularly popular in the Akkadian period. In this case, the birdman seems to be portrayed in an antagonistic manner.

\section{AKKADIAN PERIOD}

The Akkadian period witnessed the continuation of the motif of the boat-god procession. One representation (Fig. 5a) of this group is extremely interesting, as it depicts two figures of the birdman standing side by side and holding the ears of cereal in their hands. ${ }^{33}$ Even more importantly, both hybrids wear horned crowns, which mean that they were depicted as deities, perhaps minor deities of vegetation. The boat-god carries seated Shamash, and the entire design is complemented by a bull or a lion figure, a plough, a vessel, a fish symbolising the water the boat is drifting on, and a human-faced quadruped, following the boat.

A substantial majority of Akkadian glyptics with the birdman motif depict a scene of leading the hybrid, usually restrained, before an enthroned deity (Fig. 5b). These artefacts account for about $58 \%$ of all hybrid representations, both from the Early Dynastic and the Akkadian periods, and $86 \%$ of Akkadian representations only. This demonstrates the extraordinary popularity and universality of the scene, which is commonly interpreted as a scene of judgement. ${ }^{34}$ Initially, the god sitting on the throne was interpreted as Shamash, ${ }^{35}$ but the recurring symbols of the deity, namely streams of water flowing out of shoulders or hips, bowls overflowing with water or fish surrounding the figure, strongly suggest that a more plausible identity, if an accurate identification is at all possible, would be that of Enki. ${ }^{36}$ It was also assumed that this motif emerged in the Akkadian period and testified to the profound change that occurred in the perception of the birdman, namely its supposed evolution from a non-aggressive character into a villain. ${ }^{37}$ However, the above-discussed Early Dynastic artefact from Tell Brak clearly demonstrates that this motif appeared earlier than it was initially thought (Fig. 4b). Perhaps the popularity of certain types of representations of the birdman changed over time, increasing and decreasing periodically or locally, but this does not prove that the mythical tale about the creature was altered, especially since its iconography and accompanying symbols remain unchanged.

The birdman is usually led by two or three deities. These could be unidentified minor gods as shown on Fig. 5b. In this case the hybrid, depicted in its canonical form, has tied hands which are held by a deity standing behind the creature. There are fetters on its neck, by which the hybrid is being led before the throne. Another minor deity is holding a stylised

\footnotetext{
33 Amiet 1952: 156; Boehmer 1965: 175; Collon 1982: 76; Ławecka 2010: 196.

34 Amiet 1952: 158 .

35 Ward 1910: 102-107.

36 Boehmer 1965: 176, P1. XLII/494.

37 Buren 1953: 53-54.
} 


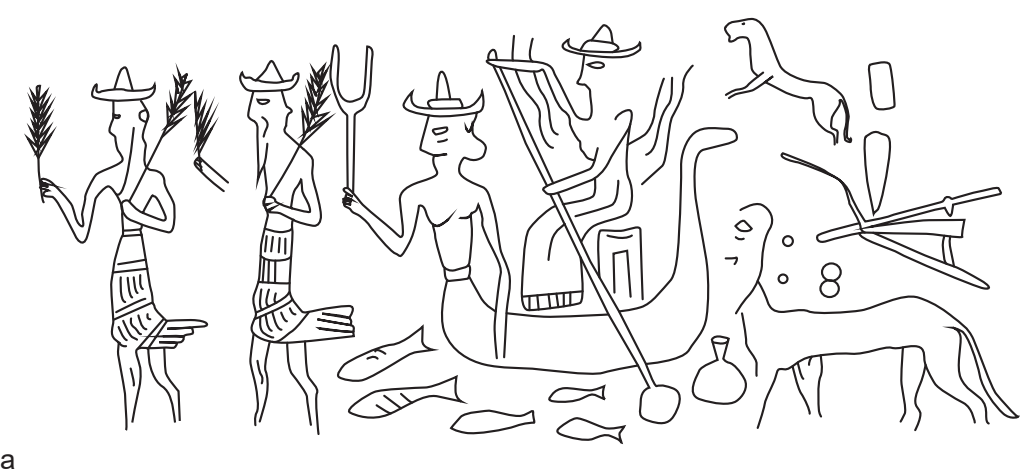

a

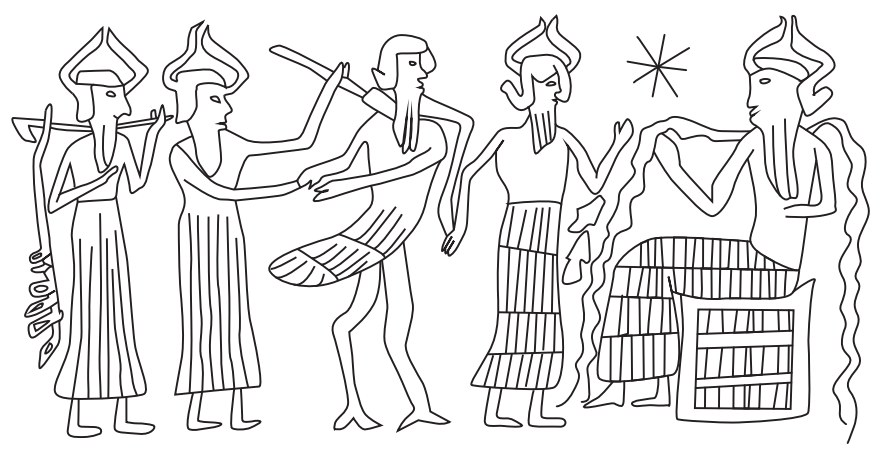

b

5a. A seal of an unknown provenance, Akkadian period; dimensions: $4.05 \times 2.61 \mathrm{~cm}$; b. a seal of an unknown provenance, Akkadian period; dimensions: 3.38 x 2.55cm; not to scale (Drawing: D. Majchrzak; based on: a. Collon 1982: Pls XXI/145, XXIX/202).

branch hanging loosely from the pole to which it is attached. Judging by the composition, the plant has been taken from the hybrid. The most important character is Enki, who is raising his hand in a greeting gesture. The scene is complemented by an eight-pointed star.

The scenes of leading the birdman before enthroned Enki sometimes also feature Usmu, a two-faced god and a minister to Enki as attested for instance on Fig. 6a. In this particular representation, the hybrid wears a horned crown demonstrating its divine status. The figure standing behind the birdman and holding it by the ear (or head) is also a deity, judging by the head-dress, but further identification is impossible as no distinguishing symbols are present. Enki is sitting on the throne, holding a bowl of streaming water in his hands. Behind the throne, a bearded man is shown wearing a loincloth and holding a standard in his hands.

Another example of this type of scene with Enki, Usmu and the birdman (Fig. 6b) also shows two unidentified deities. The first one is holding a stick resting on his shoulder, with a hanging stylised plant, which was probably seized from the birdman; the other god holds a mace, also resting on his shoulder, from which a small figure of a birdman is hanging, tied by its leg. Both the hybrid and the plant are shown as offerings to be received 


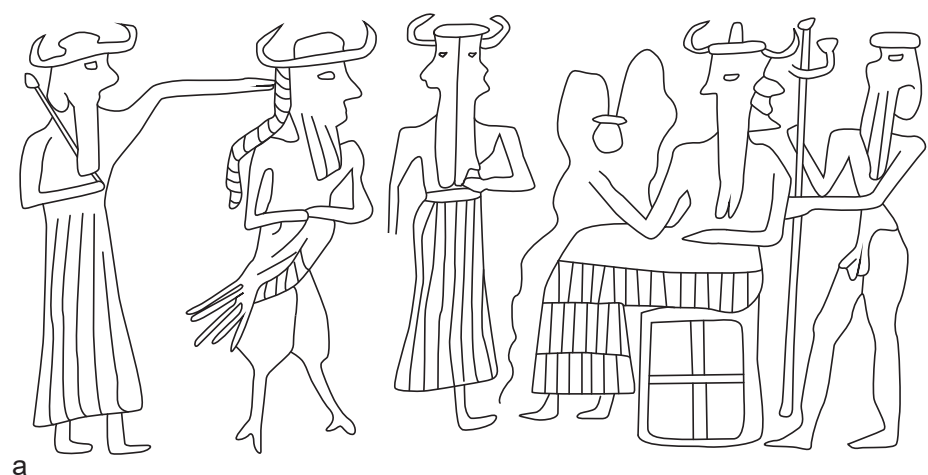

a

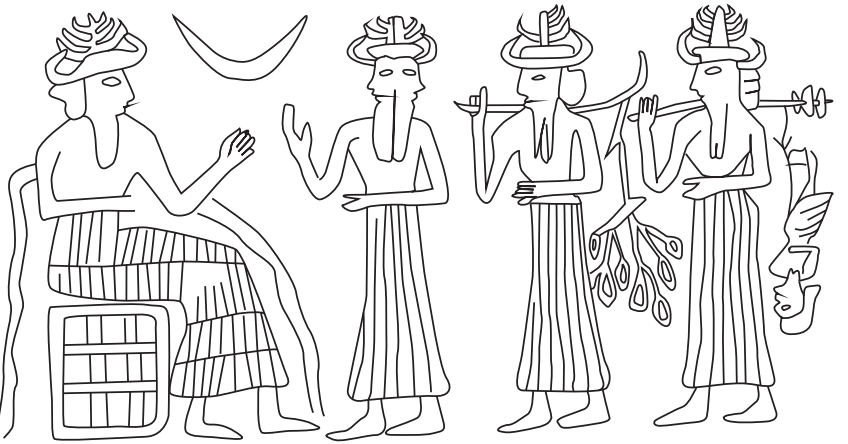

b

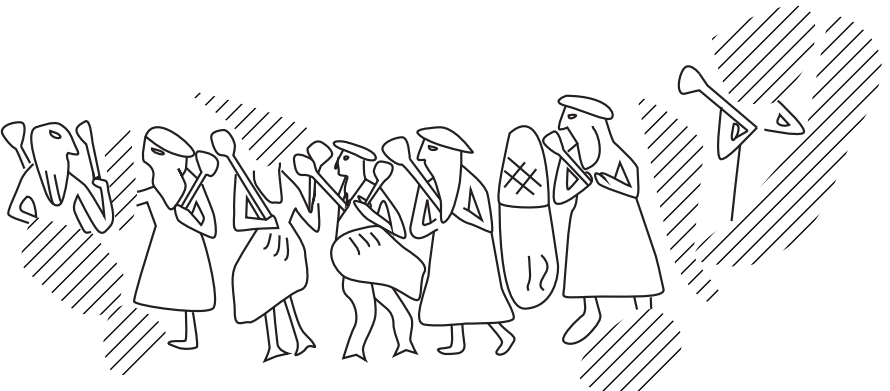

6a. A seal of an unknown provenance, Akkadian period; dimensions: 4 x 2.6cm; b. a seal of an unknown provenance, Akkadian period; dimensions: 3.25 x $1.95 \mathrm{~cm}$; c. lower register of a seal impression from Nippur, Akkadian period; not to scale (Drawing: D. Majchrzak; based on: a. Ravn 1960: no. 22; b. Boehmer 1965: Pl. XLIII/511; c. Canby 2001: Fig. 13b).

by Enki and the plant itself clearly suggests, according to the present author, the creature's connection to the world of flora and vegetation. The manner in which the birdman is carried may suggest that it is no longer alive and it was usually interpreted as such. ${ }^{38}$ However, in the art of the third millennium BC, figures of the dead are usually shown in recumbent position (see, e.g. Fig. 7a), so such a representation would be unprecedented. Perhaps the intent was to reinforce the image of the birdman's enslavement. It should be

\footnotetext{
38 Amiet 1952: 158-160.
} 
emphasised that if the creature was considered a deity, as indicated by its horned crown, then it should not be portrayed dead..$^{39}$

Apart from the continuation of the boat-god motif and the high popularity of scenes showing the captured birdman being offered to Enki, the Akkadian period also yielded examples of other representations of the hybrid. One such find is a seal impression unearthed at Nippur (Fig. 6c). ${ }^{40}$ It depicts a scene devoid of fighting, which contradicts the assertion that the representations of the hybrid at this time were only antagonistic in character. ${ }^{41}$ Instead, it is a depiction of a procession to an unidentified deity. There are two birdman figures present in this scene and each is holding a mace. While all the remaining figures are turned towards the pivotal deity, the two creatures are facing one another.

Other two representations dated to the Akkadian period depict the birdman and Shamash together, and the relation between the two is truly interesting. ${ }^{42}$ In the first example (Fig. 7a), the birdman, standing on the right, is depicted as having not only a feathered tail, bird feet and claws, but also large outstretched wings. The hybrid wears a horned crown and is the only figure present in the scene that is not standing directly on the ground, but on a naked, hunched human figure; it is holding two other figures, also naked, by their heads. This is clearly a battle scene in which the hybrid is triumphant. In the centre of the scene, Shamash is shown with sunrays emerging from his arms, clad in a long tunic and wearing a horned crown. He is holding a pruning-saw in his hand, raised above a sprawled male figure restrained by a winged deity to his left. The most important part of the scene seems to be the sun-god who alone is not fighting. Two of his allies, the birdman and the second god, also winged, are clearly winning the battle in favour of Shamash. Furthermore, neither of the hybrids is shown in a derogatory manner, but they appear to be equal to the sun-god, as both are wearing horned crowns indicative of high status.

The other seal showing the birdman in the company of Shamash (Fig. 7b) portrays a very different relationship. ${ }^{43}$ One part of the composition features a depiction of the hybrid ${ }^{44}$ which is being held by two bald figures in short tunics, probably priests. The other part is flanked on both sides by gate doors, between which Shamash is shown emerging from behind schematised mountains, with triple rays emanating from his shoulders. In this scene,

39 Black, Green 1992: 57-58.

40 The impression is two-registered, while the presented drawing contains only the lower-one. On the upper one the offering scene is depicted: Canby 2001: 13, P1. $13 \mathrm{~b}$.

41 Amiet 1952: 156-157.

42 The hybrid represented on these two seals differs from the canonical Akkadian images of birdman (in particular Fig. 7b; see below, note 43) and their identification as birdman, suggested already by Amiet (Amiet 1952: 156) may be questioned. In the present author's opinion in both above-mentioned examples the hybrid should be identified as a birdman.

43 Amiet 1952: 158, Fig. 16; Boehmer 1965: 110.

44 The manner in which the hybrid was depicted differs stylistically from the canonical representations: in this particular example, its entire torso is bird-like and the engraving suggests that its body is covered with feathers and has wings; the birdman's only human features are head and arms. Hence, there is a possibility that on this unique representation the birdman figure can symbolise some other mythological character. Nonetheless, a relation between Shamash and the birdman or bird-like figure, as it remains ambiguous, is noteworthy. 


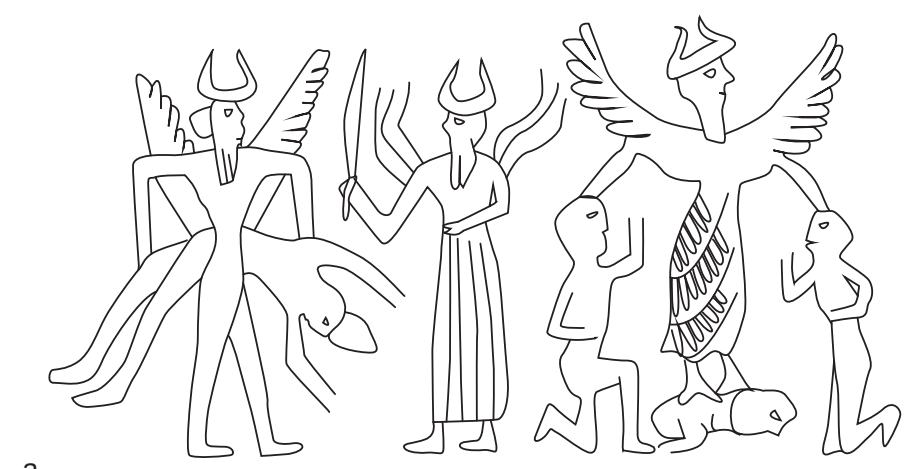

a

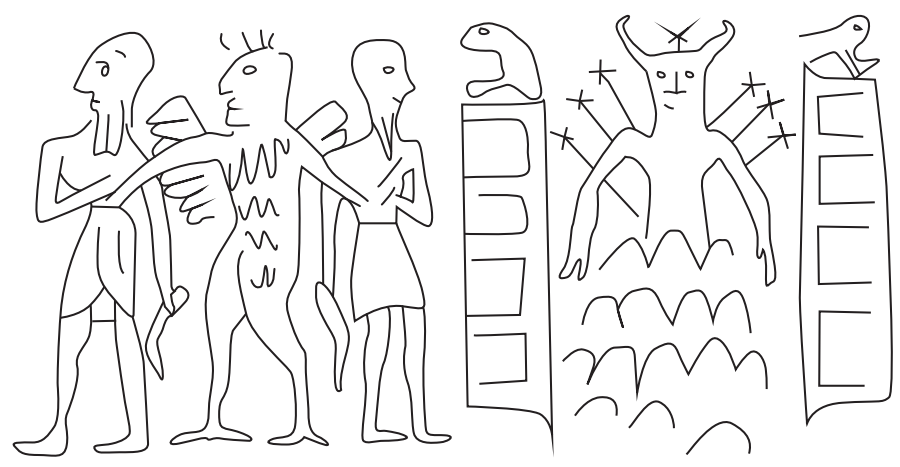

b

7a. A seal from Ur, Akkadian period; b. a seal of an unknown provenance, Akkadian period; dimensions: 3.2 x $2.1 \mathrm{~cm}$; not to scale (Drawing: D. Majchrzak; based on: Amiet 1952: Figs 14, 16).

the birdman is again an antagonistic figure, as indicated by the fact that it is constrained by the priests of Shamash. The two above-discussed representations clearly indicate that the relationship between the hybrid and the sun-god was ambiguous and they could be either allies, or opponents depending on the circumstances.

Although there were certain thematic variants of the birdman's representations in the Akkadian period, the iconography and the attributes did not change. The strong diversification of the birdman's images may testify to the multi-faceted quality of the hybrid's myth or indicate that the birdman appeared in more than one tale. Apart from the continuation of the motif of the boat-god procession involving the birdman, the creature is most often shown being led before an enthroned god, most likely Enki. In such cases, it is depicted as an antagonistic figure, usually restrained and held by a deity or deities leading it by the ear or arm. At least in one instance, the birdman is depicted as if it was dead. In addition to the examples mentioned above, the hybrid appears in battle scenes as either an adversary, or an ally of Shamash, as well as in the scene showing a procession. It is therefore impossible to unequivocally state whether the birdman was regarded as a neutral or an antagonistic figure in the glyptic art of both the Early Dynastic and the Akkadian periods. 


\section{THE BIRDMAN IN MYTHOLOGICAL CONTEXT}

As it was already mentioned, there is no certainty regarding the mythological identification of the birdman. In the studies on Mesopotamian glyptic art, the standard interpretation used to dictate that scenes with a bird-man illustrated the myth of the Anzu bird, ${ }^{45}$ especially in the case of the representations showing the birdman brought before an enthroned deity. ${ }^{46}$ Although this type of depiction might be interpreted as Enki's judgment of the Anzu bird, there are no sufficient grounds to support this hypothesis ${ }^{47}$ Furthermore, there is no indication of Anzu having any human qualities, especially not to an extent were it would be presented as half-human. The motif of Anzu was popular in the third millennium glyptics, but it was also significantly different from the birdman scenes. ${ }^{48}$ According to Henri Frankfort, the plants depicted along with the birdman were supposed to symbolise the Tablet of Destinies stolen by Anzu, but his argumentation does not seem to be very convincing. ${ }^{49}$ Furthermore, given the fact that Anzu/Imdugud is associated with Ninurta, then depictions of the birdman should be popular among the finds from Lagash state, but this is not the case. This interpretation is undermined also by the differences between these two creatures, as Anzu was an eagle-like creature, while the birdman's body is that of a waterbird..$^{50}$

Frans Wiggermann, on the other hand, tried to connect the birdman with Enmesharra, the deity of the underworld, who owns all of me, which in the first millennium $\mathrm{BC}$ was conventionally associated with the anameru plant, much like the hybrid. ${ }^{51}$ This god is sometimes associated with shushshuru, a type of pigeon. ${ }^{52}$ However, there are no indications that Enmesharra had any bird-related features, so this hypothesis cannot be verified properly.

Conversely, Amiet emphasised the relationship between the birdman (as a figure associated with vegetation) and the sun-god. He argued that the cyclical character of the sun's journey across the sky is reminiscent of the processes of growth, death and rebirth of vegetation..$^{53}$ The present author believes that this interpretation of the relationship between Shamash and the birdman is interesting and worth considering. During hot summer seasons, the sun may have caused the vegetation to wither, resulting in the loss of crops, thus symbolising Shamash's triumph and the failure of the vegetation deity. In winter, the sun disappears in the underworld, and in spring, both forces triumph together, and the rebirth of the vegetation is connected with the restoration to power of the sun-god. Such an interpretation may explain the ambiguous relation between the birdman and Shamash.

\footnotetext{
${ }^{45}$ For translation of the Middle- and the Neo-Assyrian, as well as the Neo-Babylonian variants of the Anzu bird myth, see: Vogelzang 1988: 40-47, 62-67, 71.

46 Collon 1995a: 226; Delaporte 1923: 162-163; Lambert 1966: 69-70.

47 Brentjes 1983: 90; Collon 1995a: 226; Frankfort 1955: 43.

48 Frankfort 1955: nos 519, 602; Green 1994: 243-254.

49 Frankfort 1955: 43 and n. 41.

50 Wiggermann 1994: 223; Green 1994: 249.

51 Wiggermann 1994: 223.

52 Black, Green 1992: 76.

53 Amiet 1952: 157.
} 
Amiet also suggested another mythological reference for the birdman, namely the tale of Inanna's descent into the underworld. ${ }^{54}$ Because of her association with birds, Amiet tried to combine the symbolism of the goddess with the motif of the birdman. He also noted that there was only a single seal depicting winged Inanna known from the Akkadian period, namely the Adda Seal. ${ }^{55}$ Amiet claimed that during this period, the hybrid could have symbolised the goddess, though this is nothing but a conjecture on the part of the author. ${ }^{56}$ Another argument in favour of such an interpretation would be the fact that in the myth describing Inanna's descent to the underworld, it was Enki who agreed to help her and return her to life, which could explain why this particular deity appears in the scenes together with the birdman. Van Buren also observed that the hybrid is shown standing alive before the enthroned god, which may also be indicative of Inanna's return to earth. ${ }^{57}$ In the present author opinion, this interpretation is faulty, as it was based solely on the depictions of the hybrid being led before Enki. The analysis of the motif should take into consideration all types of scenes featuring the birdman, as its iconography does not change depending on the context in Early Dynastic and the Akkadian periods. Some types of scenes, for instance the boat-god processions, do not feature a single element enabling us to connect the hybrid with Inanna. What is more, to depict this goddess as a bearded male figure with a body of a bird would be unprecedented in Mesopotamian art.

The iconographic analysis of the birdman clearly suggests its connection with vegetation and cultivation. Among Mesopotamian deities, it was Dumuzi, the shepherd god, who was associated with these aspects of life. According to the myths, Dumuzi had to spend half a year in the underworld - a predicament in which he found himself because of Inanna. ${ }^{58}$ For the other half of the year, he could re-join the world of living, thus causing the growth of plants. The image of this god, as well as his presence in the art of Mesopotamia, was heavily discussed by the scholars, yet the matter was not resolved and his iconographic identity is still uncertain. ${ }^{59}$ As Wiggermann claimed, the image of Dumuzi should emphasise the duality of nature and symbolise his relationship to vegetation and its death in the periods he spent in the underworld. Dumuzi should also have an anthropomorphic form and be easily associated with the shepherd, Inanna's lover and the ruler of Uruk. ${ }^{60} \mathrm{In}$ fact, the present author is convinced that the symbolism of the birdman and the variety of its representations seem to share many similarities with Dumuzi. According to Mircea Eliade, this god was referred to as the 'Lord of the snares', but it was he who was in fact bound and asked to be released from bondage ${ }^{61}$ which suggests a connection with the scenes of leading the restrained birdman before Enki. The depictions which show the hybrid as a part

\footnotetext{
${ }_{54}^{54}$ Amiet refers to the Sumerian version of the myth: Kramer 1944: 86-87, after Amiet 1952: 159.

${ }_{55}$ Amiet 1952: 159.

${ }^{56}$ However, such an interpretation would not explain the birdman's role in the Early Dynastic period.

57 Buren 1953: 56-57.

${ }^{58}$ Wolkstein, Kramer 1983: 51-89.

59 Wiggermann 2010: 327.

${ }^{60}$ Wiggermann 2010: 329.

${ }^{61}$ Eliade 1961: 109.
} 
of processions of the boat-god, further reinforced by symbols of a quadruped, a plough, and a ceramic vessel, may be associated with nature's rebirth in spring. In such instances, the interpretation of the birdman as a representation of Dumuzi could also be accurate. It would also account for the ambiguous relations between the birdman and Shamash, as it has been argued above. In the case of other scenes, such identification could be indicated by the hybrid's attributes. However, there are no certain indications that Dumuzi had any bird characteristics and that he should or could be associated with a half-bird creature. ${ }^{62}$ This is one of the possible interpretation of the figure. However, due to the lack of written sources and the limited number of iconographic sources, it may never be possible to fully understand the symbolism presented on the third millennium seals. As suggested by Piotr Steinkeller, many of the elements found in the glyptic art of this period illustrate tales we are not familiar with, suggesting that they originated from the still poorly understood Akkadian mythology. ${ }^{63}$

\section{CONCLUSIONS}

Several dozen known scenes involving the birdman in the glyptic art may be categorised based on the thematic variations. These are as follows: early depictions of the hybrid accompanied by animals; birdman shown with animals, fantastic creatures and human figures; boat-god processions; the hybrid being led before a deity seated on a throne (in most cases, the god in question may be identified with Enki). One should also note other depictions which do not belong to the above-specified groups, namely a procession with gifts and battle scenes featuring a sun-god.

The multi-faceted quality of the birdman's representations indicates that it was an ambiguous figure. Even the scenes where it is restrained and brought before Enki do not necessarily imply the creature's villainous or antagonistic nature; instead, they may simply emphasise the redeeming role of the enthroned god. Certainly, when discussing the iconographic motif, it is important to take into consideration both its Early Dynastic and Akkadian examples. From the stylistic perspective, it is the same character, having the same, though changeable attributes. Therefore, any attempt at associating the creature with a single myth, for instance the one of the Anzu bird or Inanna's descent to the underworld, basing on analysis of only one type of scene in which bird man appear, will fail because such an interpretation will be incomplete.

The current state of research into the art and writings of the third millennium $\mathrm{BC}$ in Mesopotamia still leaves many unexplained issues. One of them is the difficulty of identifying figures appearing in glyptic art with their counterparts in myths. The same is true in the case of the birdman. It seems that the hybrid was not intended as the focal character of the scenes, as evidenced by the recurring presence of two important Mesopotamian gods - Enki

\footnotetext{
${ }^{62}$ Unless its bird association was indicated by his relationship with Inanna, who also had bird features; nonetheless, such an interpretation seems to be far-fetched, as it has no factual grounds.

${ }^{63}$ Steinkeller 1992: 245.
} 
and Shamash - or at least of their attributes. It is possible that the scenes discussed in the present paper were primarily concerned with the story of these two deities and the birdman simply happened to play some part in these myths. Another argument supporting thesis that the hybrid was not the most important figure in these scenes is the fact that its iconography does not seem to be fully defined. The chronological sequence of glyptics with the birdman motif shows a change in the iconographic concept and the increasing or decreasing popularity of certain motifs. This does not mean, however, that the myth itself was altered. Once the canon of the birdman figure was established in the Early Dynastic III period which in itself could attest to the growth in popularity of the myth - certain aspects of its story seem to have been, at times, considered more interesting than others. It is plausible that the iconographic motif of the birdman was derived from a so far unknown myth.

\section{References}

Amiet, P. 1952: L'homme-oiseau dans 1'art mésopotamien, Orientalia 21/2, 149-167

Amiet, P. 1980: La Glyptique Mésopotamienne Archaïque, Paris

Black, J., Green, A. 1992: Gods, Demons and Symbols of Ancient Mesopotamia, An Illustrated Dictionary, London

Boehmer, R.M. 1965: Die Entwicklung der Glyptik während der Akkad-Zeit, Untersuchungen zur Assyriologie und vorderasiatischen Archäologie 4, Berlin

Brentjes, B. 1983: Alte Siegelkunst des Vorderen Orients, Leipzig

Buchanan, B. 1966: Catalogue of Ancient Near Eastern Seals in the Ashmolean Museum 1: Cylinder Seals, London

Buren, E.D. van 1933: The Flowing Vase and the God With Streams, Berlin

Buren, E.D. van 1953: An Investigation of a New Theory concerning the Bird-Man, Orientalia 22/1, 47-58

Canby, J.V. 2001: The "Ur-Nammu” Stela, University Museum Monograph 110, Philadelphia

Collon, D. 1982: Catalogue of the Western Asiatic Seals in the British Museum. Cylinder Seals II: Akkadian - Post Akkadian - Ur III Periods, London

Collon, D. 1995a: Ancient Near Eastern Art, Berkeley

Collon, D. 1995b: Filling motifs, [in:] Finkbeiner, U., Dittmann, R., Hauptmann, H. (Eds), Beiträge zur Kulturgeschichte Vorderasiens: Festschrift für Rainer Michael Boehmer, Mainz a/Rhein, 69-76

Delaporte, L. 1923: Musée du Louvre. Catalogue des cylindres, cachets et pierres gravées de style Oriental II: Acquisitions, Paris

Eliade, M. 1961: Images and Symbols. Studies in Religious Symbolism, New York Epic of Gilgamesh: The Epic of Gilgamesh. A New Translation, transl. A. George, London 1999

Frankfort, H. 1955: Stratified Cylinder Seals from the Diyala Region, OIP LXXII, Chicago Green, A. 1994: Mischwesen. B. Archäologie, [in:] Edzard, D.O. (Ed.), RLA 8, BerlinNew York, 246-264 
Hempelmann, R. 2004: „Gottschiff“ und „Zikkurratbau“ auf Vorderasiatischen Rollsiegeln des 3. Jahrtausends v. Chr., AOAT 312, Münster

Kramer, S.N. 1944: Sumerian mythology: A Study of Spiritual and Literary Achievement in the Third Millennium B.C., Philadelphia

Lambert, W.G. 1966: Ancient Near Eastern Seals in Birmingham Collections, Iraq XXVIII/1, 64-83

Ławecka, D. 2009: North Babylonian Motifs in Early Dynastic Mesopotamian Glyptic, [in:] Drewnowska, O. (Ed.), Here \& There, Across the Ancient Near East. Studies in Honour of Krystyna Łyczkowska, Warszawa, 121-148

Ławecka, D. 2010: Północna Mezopotamia w okresie wczesnodynastycznym, Warszawa Matthews, D.M. 1997: The Early Glyptic of Tell Brak, Cylinder Seals of Third Millenium Syria, OBO, Series Archaeologica 15, Fribourg-Göttingen

Matthews, R.J., Matthews, W., McDonald, H. 1994: Excavations at Tell Brak, 1994, Iraq LVI, 177-194

Moortgat, A. 1988: Vorderasiatische Rollsiegel: ein Beitrag zur Geschichte der Steinschneidekunst, Berlin

Ravn, O.E. 1960: A catalogue of Oriental Cylinder Seals and Impressions in the Danish National Museum, Copenhagen

Rova, E. 2012: A New Group of Seal Impressions from Tell Beydar, [in:] Matthews, R. et al. (Eds), Proceedings of the 7th International Congress on the Archaeology of the Ancient Near East, 12 April - 16 April 2010, the British Museum and UCL, London, vol. 3. Fieldwork \& Recent Research Posters, Wiesbaden, 151-166

Speiser, E.A. 1935: Excavations at Tepe Gawra I, Philadelphia

Steinkeller, P. 1992: Early Semitic Literature and Third Millennium Seals with Mythological Motifs, [in:] Fronzaroli, P. (Ed.), Literature and Literary Language at Ebla, QuadSem 18, Florence, 243-275

Vogelzang, M.E. 1988: Bin šar dadmē. Edition and Analysis of the Akkadian Anzu Poem, Groningen

Ward, W.H. 1910: The Seal Cylinders of Western Asia, Washington

Wiggermann, F. 1994: Mischwesen. A. Philologisch, [in:] Edzard, D.O. (Ed.), RLA 8, Berlin-New York, 222-244

Wiggermann, F. 2010: The Image of Dumuzi. A Diachronic Analysis, [in:] Stackert, J., Porter, B.M., Wright, D.P. (Eds), Gazing on the Deep: Ancient Near Eastern and Other Studies in Honor of Tzvi Abusch, Bethesda, 327-350

Wolkstein, D., Kramer, S. 1983: Inanna. Queen of the Heaven and Earth. Her Stories and Hymns from Sumer, New York 


\section{ÉTUDES et TRAVAUX XXXI / 2018}

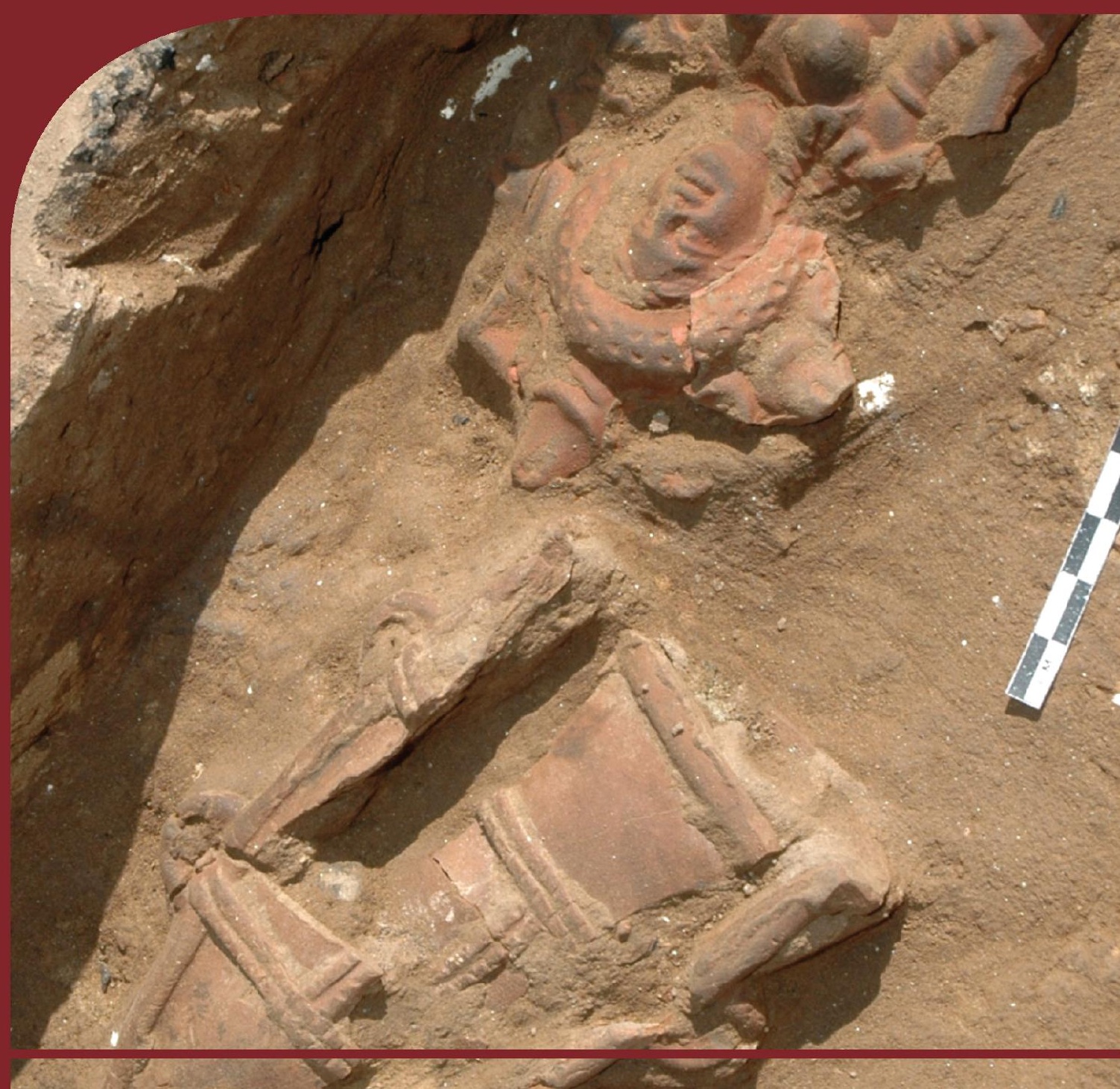

Institut des Cultures iyréditerranéennes et Oilentales FORIKSiO - de PAcadémie Polonaise des Sciences DS PA 


\section{COMITÉ DE RÉDACTION SCIENTIFIQUE}

Maciej Makowski - rédacteur en chef

Jadwiga Iwaszczuk - rédacteur

Mariusz Drzewiecki - sécretaire de la rédaction

Karol Myśliwiec - rédacteur thématique du volume

CONSEIL SCIENTIFIQUE DU JOURNAL

M. Kobusiewicz (IAE PAS, Warszawa), E. Laskowska-Kusztal (IMOC PAS, Warszawa)

D. Michaelides (University of Cyprus, Nicosia)

J.Ch. Moretti (IRAA-MOM, Université de Lyon 2/CNRS)

D. Raue (Ägyptisches Museum der Universität Leipzig), P. Reynolds (ICREA, España)

D. Welsby (British Museum, London)

\section{COMITÉ SCIENTIFIQUE DE LECTURE}

H.D. Baker (University of Toronto), P. Ballet (ArScAn-ESPRI, Université Paris Nanterre),

N. Beaux Grimal (IFAO, Cair/Collège de France, Paris), A. Dodson (University of Bristol),

L. Gabolde (CNRS), C. Gobeil (Egypt Exploration Society, London),

J. Holaubek (Institut für Ägyptologie, Wien), S. Ikram (American University in Cairo),

K. Innemée (Universiteit Leiden), Ch. Leitz (Universität Tübingen),

A. Loprieno-Gnirs (Universität Basel), Ch.E. Loeben (Museen für Kulturgeschichte, Hannover),

S. Ortisi (Universität München), A. Peignard-Giros (HiSoMA-MOM, Université de Lyon 2/CNRS),

E. Rova (Università Ca' Foscari Venezia), A. Sasson (San Diego Natural History Museum),

G. Schreiber (Eötvös Loránd University, Budapest), E. Teeter (University of Chicago),

Y. Tristant (Macquarie University, Sydney), V. Vaelske (independent researcher),

V.W.J. van Gerven Oei (independent researcher), H. Vymazalová (Charles University, Prague),

K. Winther-Jacobsen (Danish Institute at Athens),

J.A. Ostrowski, E. Papuci-Władyka, J. Śliwa (IA JU, Kraków),

R. Czerner (WUST, Wrocław), A. Ćwiek (IA AMU, Poznań),

K. Domżalski (IAE PAS, Warszawa), M. Pinker (FOS UW, Warszawa),

Ł. Niesiołowski-Spanò (IH UW, Warszawa), M. Gawlikowski (PCMA UW, Warszawa), K.O. Kuraszkiewicz (DE FOS UW, Warszawa), M. Barwik, P. Dyczek, W. Godlewski,

S. Rzepka, J. Żelazowski, A. Niwiński (IA UW, Warszawa)

\section{RÉDACTION TECHNIQUE}

Maciej Makowski, Jadwiga Iwaszczuk

CORRECTION LINGUISTIQUE

Jo Harper 
ÉTUDES et TRAVAUX

XXXI 
INSTYTUT KULTUR ŚRÓDZIEMNOMORSKICH I ORIENTALNYCH POLSKIEJ AKADEMII NAUK

\title{
STUDIA i PRACE
}

XXXI

\author{
gO IKŚiO \\ ESA PAN \\ WARSZAWA \\ 2018
}


INSTITUT DES CULTURES MÉDITERRANÉENNES ET ORIENTALES DE L'ACADÉMIE POLONAISE DES SCIENCES

\section{ÉTUDES et TRAVAUX}

XXXI

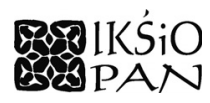

VARSOVIE

2018 
Publication scientifique financée dans le cadre du programme du Ministre de la Science et de l'Éducation Supérieure « Programme National de Développement de l'Humanistique » pour les années 2016-2021 (projet $n^{\circ} 3 \mathrm{bH} 15009983$ )

\title{
Harodowy PROGRAM ROZWOJU HUMANISTYKI
}

\author{
Copyright $($ ) \\ Instytut Kultur Śródziemnomorskich i Orientalnych PAN \\ et les Auteurs \\ Warszawa 2018
}

ISSN 2084-6762

(avant $2011: 0079-3566$ )

e-ISSN 2449-9579

Version première en papier, imprimée en Pologne - 150 copies

Version électronique accessible sur http://www.etudesettravaux.iksiopan.pl

Édition: Polskie Towarzystwo Historyczne et Wydawnictwo Neriton, Warszawa

Conception générale de couverture : J. Iwaszczuk Photo de couverture : P. Moser (C) Schweizerisches Institut für Ägyptische Bauforschung und Altertumskunde in Kairo

(terre cuites d'Aswan/Syene) 


\section{Table des matières}

KAROL MYŚLIWIEC

$(E T=E t u d T r a v / 50) \times 30$

HASSAN Aglan

Hatshepsut and the Apis Race: New Quartzite Relief Fragments

from Dra' Abu el-Naga

Amgad Joseph

Divine Wrath in Ancient Egypt

Amgad Joseph

Pain Infliction, Inflictors and Healers in Egyptian Religious, Magical

and Literary Perceptions

MirosŁaW BarwiK

New Dipinti in the Birth Portico of the Hatshepsut Temple at Deir el-Bahari

KrzyszTOF BorysŁaWsKi, ANNA NiwiŃSKA, ANDRZEJ NiwiŃSKI,

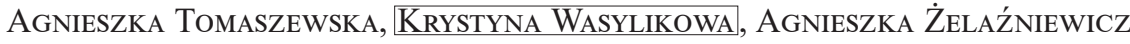

A Bulb of Narcissus on the Egyptian Mummy from University

of Wrocław Collection

LINDA CHAPON

Some Reliefs Representing the King in the Heb Sed Robe Discovered in the Henket-Ankh

Philippe Guillaume

Debunking the Latest Scenario on the Rise of the Pork Taboo

Mariola Hepa

A Clay Gladius Scabbard from Area 13c in the Ancient Roman Town of Syene

Emanuele E. Intagliata

Pinpointing Unrest at Palmyra in Early Islamic Period. The Evidence from Coin Hoards and Written Sources 
KATARZYNA KAPIEC

The Sacred Scents: Examining the Connection Between the ' $n t j w$ and $s f \underline{t}$ in the Context of the Early Eighteenth Dynasty Temples

DOMINIKA MAJCHRZAK

Remarks on the Iconographic Motif of the Birdman in Mesopotamian Glyptic Art of the Third Millennium BC

KAROLINA PAWLIK

Stone Artefacts from Late Roman Occupation Phases in Nea Paphos

ABRÉVIATIONS 
THE VOLUME IS PUBLISHED TO CELEBRATE

THE $50^{\text {TH }}$ ANNIVERSARY

OF THE

ÉTUDES ET TRAVAUX

ESTABLISHED IN 1966 